\title{
Validation of a 4-Item Score Predicting Hip Fracture and Mortality Risk Among Elderly Women
}

\author{
Daniel M. Albertsson, $M D^{1,2}$ \\ Dan Mellström, MD, $P b D^{3}$ \\ Christer Petersson, MD, $\mathrm{PbD}^{2}$ \\ Robert Eggertsen, $M D, P b D^{1,4}$ \\ 'Department of Primary Health Care, \\ Sahlgrenska Academy at Göteborg \\ University, Göteborg, Sweden \\ ${ }^{2}$ R\&D Center, Kronoberg County Council, \\ Växjö, Sweden \\ ${ }^{3}$ Department of Geriatrics, Sahlgrenska \\ Academy at Göteborg University, \\ Göteborg, Sweden \\ ${ }^{4}$ Mölnlycke Primary Health Care and \\ Research Center, Mölnlycke, Sweden
}

Conflicts of interest: none reported

\section{CORRESPONDING AUTHOR}

Daniel M. Albertsson, MD

FoU-centrum

Box 1223, SE-351

12 Växjö, Sweden

daniel.albertsson@1tkronoberg.se

\begin{abstract}
PURPOSE One in 4 Swedish women experiences a hip fracture, an event that has high concomitant morbidity and mortality. We developed and validated a clinical predictor of fracture and mortality risk, the Fracture and Mortality (FRAMO) Index.

METHODS This was a population-based prospective cohort study with a baseline questionnaire and 2-year outcomes of hip fracture, fragility fracture, and death. The questionnaire was sent to 1,498 women aged 70 years or older in 3 rural populations, asking them about their age, weight, height, mobility, previous fractures, smoking, medication use, and housing. Some women were also asked about previous vertebral radiographs. We defined 2 risk models before outcome data collection and subsequently renamed 1 model (age $\geq 80$ years, weight $<60$ $\mathrm{kg}$, previous fragility fracture, and the need to use arms to rise from the sitting position) the FRAMO Index. We used logistic regression analysis to study the association between the FRAMO Index and outcomes in all participants.
\end{abstract}

RESULTS The participation rate was $83 \%$ in this elderly female population ( $\mathrm{N}=$ 1,248). The $63 \%$ of women with 0 to 1 risk factor had a 2-year hip fracture risk of $0.8 \%$ and mortality risk of $3.2 \%$. In contrast, women with 2 to 4 risk factors had a 2-year hip fracture risk of $5.4 \%$ (odds ratio $=7.5 ; 95 \%$ confidence interval, 3.0-18.4) and mortality risk of $23.7 \%$ (odds ratio $=9.5 ; 95 \%$ confidence interval, 6.0-14.9). These differences remained significant after adjustment for age as a continuous variable. Mortality increased with the number of risk factors. The proportion of women reporting previous vertebral fractures was higher among the group specifically questioned about vertebral radiographs $(P<.001)$.

CONCLUSIONS The FRAMO Index identified the majority of women who experienced hip fractures during a 2-year follow-up, who might have been candidates for intensified preventive measures. The FRAMO Index, based on 4 binary risk factors, would be practical for routine use in primary care.

Ann Fam Med 2007;5:48-56. DOI: 10.1370/afm.602.

\section{INTRODUCTION}

厂 ip fracture is an increasing problem worldwide. ${ }^{1}$ One in 4 Swedish women (23\%) experiences a hip fracture during her lifetime, an event that is associated with $20 \%$ mortality within 1 year. ${ }^{2,3}$ There are several methods for fracture prevention, although they are underused in routine health care.

Combinations of low bone mineral density (BMD) with certain clinical risk factors are associated with an increased risk of hip fracture, ${ }^{4-8}$ but low BMD alone is less predictive of fracture. ${ }^{4,9,10}$ Many individuals who have an elevated risk of hip fracture might be identified by clinical risk factors alone. ${ }^{4,5,11}$ Previously described risk factor models for hip fracture are fairly complicated, requiring several weighted variables. Six clinical risk factors (2 weighted) and BMD assessment predicted fractures in the 
Study of Osteoporotic Fractures (SOF), and this risk factor combination was validated in another elderly community-based female population, the European Patent Information and Document Service (EPIDOS) fracture study. ${ }^{5}$ That study found that the combination had a sensitivity of $78.6 \%$ and specificity of $61.7 \%$ for predicting hip fracture within 5 years. The Melton Osteoporotic Fracture (MOF) study investigated 6 weighted clinical risk factors in an elderly female population in primary care and found that this combination had a sensitivity of $84 \%$ and specificity of $68 \%$ for hip fracture within 3 years. ${ }^{11}$

In this study, we selected 5 established clinical risk factors for hip fracture that we expected would be easy to ascertain and prevalent among elderly women. ${ }^{4,5,9,12-14}$ By combining only 4 of these factors and creating risk indices, we aimed to facilitate risk factor assessment during routine consultations. The goal of our study was to develop and validate a practical tool for hip fracture risk assessment and assess its ability to predict fractures and total mortality.

\section{METHODS}

\section{Study Population}

Our study population was drawn from 1,498 women aged 70 years or older living in 3 rural primary health care districts in southern Sweden. They were recruited from the National Swedish Population Register in November 2001. We selected the entire female population in the Vislanda district (501 women) and a similar number of age-matched women from each of 2 other districts, Tingsryd and Emmaboda. The Regional Ethics Committee at the University of Lund approved the study (LU 406-00).

\section{Questionnaire Data and Follow-up}

We sent the women a 22-item questionnaire focused on risk factors for fracture, combined with brief advice on fracture prevention. A relative or caregiver was allowed to assist women in answering the questions, most of which were multiple choice. Nonresponders were reminded twice by mail within 2 months.

We tested 2 risk models (described further below). The questions used for risk model 1 were age, weight, need to use arms to rise from the sitting position, and previous fragility fracture after age 40 (Table 1). These risk factors and questions about falls during the last year, maternal history of hip fracture, current height, and health perception were similar to the questions in the study by Cummings et al. ${ }^{4}$ Questions about previous fracture, smoking, and use of cortisone medication were used in the Scandinavian Scandos study. ${ }^{14}$ In a previous study among 73 women in the Vislanda district, the question about previous fragility fracture had a 3-year reliability of $94 \%$ (17 of 18 responses agreeing). ${ }^{15}$ If the location of a reported fragility fracture was uncertain, we determined the location by using the primary care system's radiology data bank, which recorded fractures since 1994 or 1999 in these 3 districts. We did not search medical records for earlier radiology results.

We asked the Vislanda population additional specific questions about previous vertebral fractures (Table 1) and about their interest in follow-up. Follow-up consisted of a heel BMD measurement by the dual x-ray and laser technique (DXL Calscan bone densitometer, Demetech, Täby, Sweden), ${ }_{1}^{16}$ beginning at the end of 2003, and home visits by nurses during 2003 and 2004. If women reported a vertebral fracture diagnosed by radiograph, we classified the fracture as a previous fragility fracture.

\section{Risk Models and Ascertainment of Fractures and Mortality}

We tested 2 models for risk assessment. Risk model 1 included 4 predefined factors: age 80 years or older, weight less than $60 \mathrm{~kg}$, previous fragility fracture, and need to use arms to rise from the sitting position. Risk model 2 included the same risk factors, except that need to use arms to rise was replaced by falls during the last 12 months. For both models, we compared women with at least 2 of 4 risk factors with women with 0 or 1 risk factor. We tested each model as a predictor of future hip fracture, fragility fracture, and total mortality during a 2-year period, both in the whole population and in subpopulations.

We defined new fragility fractures as fractures

\section{Table 1. Questions Used to Assess the 4 Risk Factors in Risk Model 1}

\begin{tabular}{|c|c|}
\hline Question & Points \\
\hline \multicolumn{2}{|l|}{ 1. What is your present age? } \\
\hline$\geq 80$ y & 1 \\
\hline $70-79$ y & 0 \\
\hline \multicolumn{2}{|l|}{ 2. What is your current weight? } \\
\hline$<60 \mathrm{~kg}$ & 1 \\
\hline$\geq 60 \mathrm{~kg}$ & 0 \\
\hline \multicolumn{2}{|l|}{$\begin{array}{l}\text { 3. Can you rise } 5 \text { times from a chair without using your } \\
\text { arms? (Try if you want.) }\end{array}$} \\
\hline No, I must use my arms to rise & 1 \\
\hline Yes & 0 \\
\hline \multicolumn{2}{|l|}{$\begin{array}{l}\text { 4. Have you broken any bones after the age of } 40 y \text { ? } \\
\text { If so, which bone? }\end{array}$} \\
\hline \multicolumn{2}{|l|}{ Have your vertebrae been x-rayed?* } \\
\hline $\begin{array}{l}\text { Fracture of wrist/lower arm, upper arm, hip, or verte- } \\
\text { brae, or vertebral compression seen on radiograph }\end{array}$ & 1 \\
\hline No fracture, or fracture in some other location & 0 \\
\hline
\end{tabular}


occurring in the hip, wrist, proximal humerus, pubic bone, ischial bone, and vertebrae during 2002-2003. Vertebral fractures were classified as new if the radiograph report confirmed vertebral compression in women who had local pain. We thoroughly identified all incident fractures using diagnosis registers from the departments of orthopedics and geriatrics and using radiograph reports. We used ICD-10 (International Classification of Diseases, 10th Revision) diagnostic codes, specifically codes S72.00-72.21, S52.50-51, S42.20-21, S32.50, S32.80, S22.00, and S32.00, for the Vislanda and Tingsryd populations. Outpatient care registers were incomplete for the Emmaboda population; therefore, we documented only hip fractures (ICD-10 codes S72.00-72.21) for this population. We ascertained mortality in the study population by using data from the National Swedish Population Register.

\section{Statistical Analysis}

We calculated odds ratios (ORs) and hazard ratios (HRs) with logistic and Cox regression analysis for variables with cell values greater than 4 . In the predefined risk models, women with missing data were recoded as having a low fracture risk to avoid overestimating the risks, while still evaluating the remaining risk factors for all participants. We used the Fisher exact test or the $\chi^{2}$ test to compare binary variables between 2 independent groups; variables with cell values of less than 5 were analyzed with the Fisher test only. We used the $t$ test or Wilcoxon test for continuous symmetric or skewed variables. Kaplan-Meier curves were compared by the Breslow test. The areas under the receiver operating characteristic (ROC) curves were calculated for the risk models as binary or as predicted probabilities, as one measure of risk model discrimination. We regarded 2 -sided $P$ values of less than .05 to be significant and used exact tests whenever possible. We used the statistical programs SPSS 13.0 (Statistical Package for the Social Sciences; SPSS Inc, Chicago, Ill) and Epi
Info 6.0 (Centers for Disease Control and Prevention, Atlanta, Ga).

\section{RESULTS}

\section{Response Rate and Baseline Characteristics}

The response rate to the questionnaire was $83 \%$. The 250 nonrespondents (17\%) were 3.4 years older than the respondents $(P<.001)$.

The response rates for individual questions and the baseline characteristics of respondents are given in Table 2. The 1,248 women included in analyses ranged

\section{Table 2. Response Rates and Distributions for 19 Possible Risk Factors in the Questionnaire Completed by Women Aged $\geq 70$ Years in $2001(\mathrm{~N}=1,248)$}

\begin{tabular}{|c|c|c|c|}
\hline Characteristic & $\begin{array}{c}\text { Response } \\
\text { Rate } \\
\text { No. (\%) }\end{array}$ & $\begin{array}{c}\text { Study } \\
\text { Population } \\
\text { No. or Mean } \\
\text { Value* }\end{array}$ & $\%^{+}$ \\
\hline \multicolumn{4}{|l|}{ Continuous risk factors } \\
\hline Age, y & $1,248(100.0)$ & $78.8 \pm 6.5$ & - \\
\hline Weight, kg & $1,214(97.2)$ & $67.3 \pm 11.8$ & - \\
\hline Height, $\mathrm{cm}$ & $1,213(97.1)$ & $161 \pm 6.1$ & - \\
\hline Dairy calcium intake, mg/d & $1,208(96.7)$ & $628 \pm 292$ & - \\
\hline \multicolumn{4}{|l|}{ Predefined risk factors } \\
\hline \multicolumn{4}{|l|}{ Age, y } \\
\hline 70-74 & $1,248(100.0)$ & 377 & 30.2 \\
\hline $75-79$ & $1,248(100.0)$ & 382 & 30.6 \\
\hline $80-84$ & $1,248(100.0)$ & 236 & 18.9 \\
\hline $85-89$ & $1,248(100.0)$ & 156 & 12.5 \\
\hline $90-100$ & $1,248(100.0)$ & 97 & 7.8 \\
\hline Weight $<60$ kg & $1,214(97.2)$ & 302 & 24.9 \\
\hline Fragility fracture after age $40 y^{\ddagger \S}$ & $1,205(96.6)$ & 398 & 33.0 \\
\hline Uses arms when rising 5 times from chair & $1,210(97.0)$ & 362 & 29.9 \\
\hline Fell during last $12 \mathrm{mo}$ & $1,192(95.4)$ & 397 & 33.3 \\
\hline \multicolumn{4}{|l|}{ Other possible risk factors } \\
\hline Any type of fracture after age $40 y^{\S}$ & $1,210(97.0)$ & 486 & 40.2 \\
\hline Use of cortisone medication for $>3 \mathrm{mo}$ & $1,158(92.7)$ & 149 & 12.9 \\
\hline Has never given birth & $1,238(99.1)$ & 164 & 13.2 \\
\hline Lives in residential care (vs community) & $1,231(98.6)$ & 123 & 10.0 \\
\hline Height $>167 \mathrm{~cm}$ & $1,213(97.1)$ & 183 & 15.1 \\
\hline Dairy calcium intake $<500 \mathrm{mg} / \mathrm{d}$ & $1,208(96.7)$ & 377 & 31.2 \\
\hline Impaired vision, self-reported (vs good vision) & $1,226(98.2)$ & 356 & 29.0 \\
\hline History of maternal hip fracture & $1,108(88.7)$ & 123 & 11.1 \\
\hline Subjective health poor (vs excellent or fair) & $1,224(98.0)$ & 120 & 9.8 \\
\hline Current smoking & $1,231(98.6)$ & 53 & 4.3 \\
\hline Daily coffee intake $\geq 2$ cups (vs $0-1$ cup) & $1,233(98.7)$ & 1,040 & 84.3 \\
\hline Menopausal age $<45$ y & $1,072(85.8)$ & 128 & 11.9 \\
\hline No daily medication" & $1,229(98.4)$ & 152 & 12.4 \\
\hline $\begin{array}{l}\text { Any parent of non-Nordic origin } \\
\text { (vs Nordic)" }\end{array}$ & $1,226(98.2)$ & 23 & 1.9 \\
\hline \multicolumn{4}{|c|}{$\begin{array}{l}\text { * Mean value is given as arithmetic mean } \pm \text { SD. } \\
\text { † Estimated percentage for participants with valid data for that measure. } \\
\text { † Previous fragility fracture in hip, lower arm, upper arm, or vertebrae after age } 40 \text { years. } \\
\S \text { Only the Vislanda population was asked the additional question about vertebral radiographs. } \\
\text { |l This subgroup expected to have lower fracture risk. }\end{array}$} \\
\hline
\end{tabular}




\begin{tabular}{|c|c|c|c|c|c|c|}
\hline Characteristic & $\begin{array}{l}\text { Hip } \\
\text { Fracture } \\
(n=31) \\
\text { No. }(\%)^{*}\end{array}$ & $\begin{array}{l}\text { No Hip } \\
\text { Fracture } \\
(n=1,217) \\
\text { No. }(\%)^{*}\end{array}$ & $\underset{\text { Exact }^{\dagger}}{P}$ & $\begin{array}{l}\text { Univariate } \\
\text { HR }(95 \% \mathrm{Cl})\end{array}$ & $\begin{array}{l}\text { Multivariate }^{\ddagger} \\
4 \text { Risk Factors } \\
\text { HR }(95 \% \mathrm{Cl})\end{array}$ & 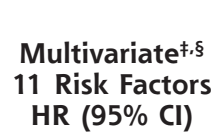 \\
\hline \multicolumn{7}{|l|}{ Predefined risk factors } \\
\hline Age $80-100$ y & $19(61)$ & 470 (39) & .011 & $2.7(1.3-5.6)^{\|}$ & $2.2(0.99-4.7)$ & $2.0(0.9-4.7)$ \\
\hline Weight $<60 \mathrm{~kg}$ & $15(48)$ & $287(24)$ & $.005 \|$ & $3.1(1.5-6.2)^{\|}$ & $2.4(1.2-5.0)^{\|}$ & $2.6(1.2-5.8)^{\|}$ \\
\hline Fragility fracture after age $40 y^{\natural, \#}$ & $17(55)$ & $381(32)$ & $.01 \|$ & $2.5(1.3-5.2)^{\|}$ & $2.3(1.1-4.7)^{\|}$ & $2.6(1.2-5.6)^{\|}$ \\
\hline $\begin{array}{l}\text { Uses arms when rising } 5 \text { times from } \\
\text { chair }\end{array}$ & $14(47)$ & $348(30)$ & .07 & $2.3(1.1-4.7)^{\|}$ & $1.7(0.8-3.6)$ & $1.5(0.6-3.7)$ \\
\hline Fell during last $12 \mathrm{mo}$ & $12(41)$ & $385(33)$ & .42 & $1.5(0.7-3.1)$ & - & $1.0(0.4-2.3)$ \\
\hline \multicolumn{7}{|l|}{ Other possible risk factors } \\
\hline Any type of fracture after age $40 y^{\#}$ & $19(61)$ & $468(40)$ & $.02 \|$ & $2.4(1.7-5.0) \|$ & - & - \\
\hline Use of cortisone medication for $>3 \mathrm{mo}$ & $7(26)$ & $142(13)$ & .07 & $2.4(1.0-5.6)^{\|}$ & - & $2.6(1.1-6.3)^{\|}$ \\
\hline Has never given birth & $8(26)$ & $156(13)$ & .054 & $2.4(1.1-5.4)^{\|}$ & - & $2.4(1.0-5.6)$ \\
\hline Lives in residential care (vs community) & $7(23)$ & $116(10)$ & $.03 \|$ & $3.3(1.4-7.8)^{\|}$ & - & $1.8(0.6-5.0)$ \\
\hline Height $>167 \mathrm{~cm}$ & $5(17)$ & $178(15)$ & .80 & $1.1(0.4-2.9)$ & - & $1.2(0.4-3.5)$ \\
\hline Dairy calcium intake $<500 \mathrm{mg} / \mathrm{d}$ & $9(31)$ & $368(31)$ & 1.00 & $1.0(0.5-2.2)$ & - & $1.0(0.4-2.2)$ \\
\hline $\begin{array}{l}\text { Impaired vision, self-reported } \\
\text { (vs good vision) }\end{array}$ & $8(26)$ & $348(29)$ & .84 & $0.9(0.4-2.0)$ & - & $0.5(0.2-1.3)$ \\
\hline History of maternal hip fracture & $4(15)$ & $119(11)$ & .52 & - & - & - \\
\hline $\begin{array}{l}\text { Subjective health poor (vs excellent or } \\
\text { fair) }\end{array}$ & $1(3)$ & $119(10)$ & .36 & - & - & - \\
\hline Current smoking & $0(0)$ & $53(4)$ & .64 & - & - & - \\
\hline Daily coffee intake $\geq 2$ cups (vs $0-1$ cup) & $28(93)$ & $1,010(84)$ & .21 & - & - & - \\
\hline Menopausal age $<45$ y & $4(18)$ & $124(12)$ & .32 & - & - & - \\
\hline No daily medication** & $2(6)$ & $150(12)$ & .42 & - & - & - \\
\hline $\begin{array}{l}\text { Any parent of non-Nordic origin } \\
\text { (vs Nordic)** }\end{array}$ & $2(7)$ & $21(2)$ & .10 & - & - & - \\
\hline \multicolumn{7}{|l|}{$\mathrm{HR}=$ hazard ratio; $\mathrm{Cl}=$ confidence interval. } \\
\hline \multicolumn{7}{|c|}{$\begin{array}{l}\text { † Exact } P \text { value according to the Fisher exact test, } 2 \text {-sided. } \\
\text { ‡ Cox regression analysis (for time alive before hip fracture) for participants with valid data and only for variables with cell values greater than } 4 . \\
\text { § The variable "any type of fracture" was excluded from multivariate analysis because it competed with and was highly correlated with "previous fragility fracture." } \\
\| P<.05\end{array}$} \\
\hline
\end{tabular}

in age from 70 to 100 years (mean, 78.8 years). Ten percent lived in residential care.

Response rates for the 5 predefined risk factors included in the risk models averaged 97\% (range, 95\% $100 \%)$. Only 3 risk factor questions had a response rate of less than $95 \%$.

One third (33\%) of the study population reported having falls during the last 12 months, and $40 \%$ reported experiencing fractures after the age of 40 . Each of the 5 predefined risk factors was found in $25 \%$ to $39 \%$ of the participants.

\section{Risk Factors for Hip Fracture}

Thirty-one women experienced at least 1 hip fracture during the study period, a cumulative annual incidence of $1.2 \%$. This incidence did not differ between the Vislanda and the remaining districts studied $(P=.38)$.
Compared with women who did not experience hip fractures, women who did were 4.2 years older ( 82.9 vs 78.7 years), weighed $6.8 \mathrm{~kg}$ less (60.7 vs $67.5 \mathrm{~kg}$ ), and had a higher mean number of previous fragility fractures (0.84 vs 0.54 fractures) $(P<.01$ for each comparison).

In univariate Cox regression analysis, 4 of the 5 predefined risk factors were associated with an increased risk of hip fracture (Table 3 ). Of the remaining 14 risk factors, 4 were associated with an increased hip fracture risk (any type of fracture, use of cortisone medication, nulliparity, and living in residential care). After adjustment for age as a continuous variable, the factors still significantly associated with the risk of hip fracture were a low body weight $(\mathrm{HR}=2.4 ; 95 \%$ confidence interval $[\mathrm{CI}], 1.2-5.0)$, previous fragility fracture $(\mathrm{HR}=2.2 ; 95 \% \mathrm{CI}, 1.1-4.4)$, and any type of fracture $(\mathrm{HR}=2.1 ; 95 \% \mathrm{CI}, 1.0-4.4)$. 
After multiple Cox regression analysis of the 4 predefined risk factors that were significant predictors in univariate analysis, low body weight and previous fragility fracture remained significant predictors (Table 3). Use of cortisone medication was also a significant predictor when the multiple analysis was based on 11 risk factors.

The predefined risk factors for hip fracture also predicted all-cause mortality in this cohort (Table 4). Four women (13\%) died within 1 year after their hip fracture. During 2003, the corresponding 1-year mortality for women who did not experience an incident hip fracture was $6 \%(\mathrm{OR}=2.5 ; 95 \% \mathrm{CI}, 0.7-7.7)$.

\section{Assessment of Fracture and Mortality Risk}

The total annual mortality rate was $5.4 \%$ in this study population, and 134 women died during 2002-2003.
The associations between the 5 main risk factors according to the 2 predefined risk models and outcomes are shown in Table 4. Both models significantly predicted hip fracture, fragility fracture, and mortality for the whole population, but risk model 1 had higher ORs (Table 4). In further analyses, we applied risk model 1, renamed the Fracture and Mortality (FRAMO) Index, to all 1,248 participants.

The FRAMO Index was strongly associated with hip fracture, fragility fracture, and mortality risk within 2 years, with ORs of 7.5, 6.7, and 9.5, respectively (Table 4 and Figure 1). All lower limits of the 95\% CIs were 3.0 or higher for these 3 ORs.

Even when adjusted for age as a continuous variable in multivariate logistic regression analysis, the FRAMO Index had an OR of 6.8 (95\% CI, 2.4-19.5) for hip fracture and an OR of 4.3 (95\% CI, 2.5-7.4) for

Table 4. Hip Fracture, Fragility Fracture, or Death Within 2 Years, Predicted by 2 to 4 vs 0 to 1 Risk Factors, According to Risk Model

\begin{tabular}{|c|c|c|c|c|c|c|c|c|c|}
\hline \multirow[b]{2}{*}{ Risk Model } & \multicolumn{7}{|c|}{$\begin{array}{l}\text { Total Population } \\
(N=1,248)\end{array}$} & \multirow{2}{*}{$\begin{array}{c}\text { Vislanda } \\
(n=435) \\
P \text { Exact }\end{array}$} & \multirow{2}{*}{$\begin{array}{c}\text { Tingsryd } \& \\
\text { Emmaboda } \\
\text { (n = 418 } \\
\& \text { 395) } \\
P \text { Exact }\end{array}$} \\
\hline & $\begin{array}{c}\text { Total } \\
\mathrm{N}\end{array}$ & $\begin{array}{c}\text { Events } \\
n\end{array}$ & $\begin{array}{c}\text { No Events } \\
n\end{array}$ & $\begin{array}{c}\text { NPVI } \\
\text { PPV (\%) }\end{array}$ & $\begin{array}{c}\text { Specificityl } \\
\text { Sensitivity (\%) }\end{array}$ & $\begin{array}{l}\text { Odds Ratio } \\
\text { (95\% Cl) }\end{array}$ & $P$ Exact & & \\
\hline \multicolumn{10}{|c|}{ Risk model 1 (FRAMO Index): Age, weight, previous fragility fracture, ${ }^{*, \dagger}$ and using arms to rise } \\
\hline \multicolumn{10}{|c|}{ Hip fractures } \\
\hline 0-1 risk factor & 789 & 6 & 783 & \multirow{2}{*}{$99.2 / 5.4$} & \multirow{2}{*}{$64 / 81$} & 1.0 & \multirow{2}{*}{$<.001^{\ddagger}$} & \multirow{2}{*}{$<.001^{\ddagger}$} & \multirow{2}{*}{$.002^{\S}$} \\
\hline 2-4 risk factors & 459 & 25 & 434 & & & $7.5(3.0-18.4)^{\ddagger}$ & & & \\
\hline \multicolumn{10}{|c|}{ Fragility fractures"l, } \\
\hline 0-1 risk factor & 547 & 9 & 538 & \multirow{2}{*}{$98.4 / 10.0$} & \multirow{2}{*}{$66 / 78$} & 1.0 & \multirow{2}{*}{$<.001^{\ddagger}$} & \multirow{2}{*}{$<.001^{\ddagger}$} & \multirow{2}{*}{$.001 \S$} \\
\hline 2-4 risk factors & 306 & 31 & 275 & & & $6.7(3.2-14.3)^{\ddagger}$ & & & \\
\hline \multicolumn{10}{|l|}{ Mortality } \\
\hline 0-1 risk factor & 789 & 25 & 764 & \multirow{2}{*}{$96.8 / 24.0$} & \multirow[b]{2}{*}{$67 / 81$} & 1.0 & \multirow[b]{2}{*}{$<.001^{\ddagger}$} & \multirow{2}{*}{$<.001^{\ddagger}$} & \multirow{2}{*}{$<.001^{\ddagger}$} \\
\hline 2-4 risk factors & 459 & 109 & 350 & & & $9.5(6.0-14.9)^{\ddagger}$ & & & \\
\hline \multicolumn{10}{|c|}{ Risk model 2: Age, weight, previous fragility fracture, ${ }^{*, \dagger}$ and fall } \\
\hline \multicolumn{10}{|c|}{ Hip fractures } \\
\hline 0-1 risk factor & 775 & 9 & 766 & \multirow{2}{*}{$98.8 / 4.7$} & \multirow{2}{*}{$63 / 71$} & 1.0 & \multirow{2}{*}{$<.001^{\ddagger}$} & \multirow{2}{*}{$.001^{\S}$} & \multirow{2}{*}{.052} \\
\hline 2-4 risk factors & 473 & 22 & 451 & & & $4.1(1.9-9.1)^{\ddagger}$ & & & \\
\hline Fragility fractures & & & & & & & & & \\
\hline 0-1 risk factor & 537 & 12 & 525 & & & 1.0 & & & \\
\hline 2-4 risk factors & 316 & 28 & 288 & $9 / .8 / 8.9$ & $65 / 10$ & $4.2(2.1-8.5)^{\ddagger}$ & $<.001^{+}$ & $<.001^{\dagger}$ & $.04^{\#}$ \\
\hline Mortality & & & & & & & & & \\
\hline 0-1 risk factor & 775 & 35 & 740 & 0551210 & 66174 & 1.0 & 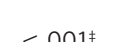 & $<\cap 01$ — & $<\mathrm{O \cap 1 \neq}$ \\
\hline 2-4 risk factors & 473 & 99 & 374 & $95.5 / \angle 1.0$ & $00 / / 4$ & $5.6(3.7-8.4)^{\ddagger}$ & $<.001^{\dagger}$ & $<.001^{\dagger}$ & $<.001^{\dagger}$ \\
\hline NPV $=$ negative pre & ve value & $P P V=p c$ & sitive predictive & ralue; $\mathrm{Cl}=\mathrm{co}$ & ifidence interval; FRA & $\mathrm{MO}=$ Fracture and & Mortality. & & \\
\hline $\begin{array}{l}\text { Note: Hypothesis tes } \\
\text { at least } 5 \text { times from } \\
\text { missing data were re } \\
\text { regression analysis. }\end{array}$ & $\begin{array}{l}\text { by the } F \\
\text { ding posit } \\
\text { ded as hat }\end{array}$ & $\begin{array}{l}\text { sher exact t } \\
\text { ion. }{ }^{* \dagger} \text { Risk } \mathrm{n} \\
\text { ing a low } \mathrm{fr}\end{array}$ & $\begin{array}{l}\text { est. } \text { Risk model } \\
\text { nodel } 2 \text { : age } \geq 8 \\
\text { racture risk; ther }\end{array}$ & $\begin{array}{l}\text { (FRAMO Inde } \\
\text { years, weight } \\
\text { efore, data for }\end{array}$ & $\begin{array}{l}\text { x): age } \geq 80 \text { years, w } \\
<60 \mathrm{~kg} \text {, previous fr } \\
\text { all } 1,248 \text { women wer }\end{array}$ & $\begin{array}{l}\text { ight }<60 \mathrm{~kg} \text {, previ } \\
\text { gility fracture, and } \\
\text { included in the Fis }\end{array}$ & $\begin{array}{l}\text { us fragility } f \\
\text { alls during } t \\
\text { her exact } 2 \text {-si }\end{array}$ & $\begin{array}{l}\text { acture, and using } \\
\text { past } 12 \text { months } \\
\text { led test and the }\end{array}$ & $\begin{array}{l}\text { arms when rising } \\
\text { Women with } \\
\text { inary logistic }\end{array}$ \\
\hline * Previous fragility $f$ & ures: frac & tures in the & hip, lower arm, & upper arm, or & vertebrae after age 4 & 0 years. & & & \\
\hline $\begin{array}{l}\text { † Included reported } \\
\ddagger P<.001 \text {. }\end{array}$ & & & & & & population. & & & \\
\hline$\S P<.01$. & & & & & & & & & \\
\hline || Fragility fractures: & ctures of & the hip, dist & al radius, proxir & al humerus, $\mathrm{p}$ & abic bone, ischial bor & e, or vertebrae duri & $\lg 2002-200$ & & \\
\hline $\begin{array}{l}\text { I Data for all types } \\
\# P<.05 \text {. }\end{array}$ & ragility $\mathrm{fr}$ & actures were & obtained only & or the Vislanda & and Tingsryd popul & tions $(n=853)$ & & & \\
\hline
\end{tabular}


mortality. The crude FRAMO Index predicted 2-year hip fracture risk with $81 \%$ sensitivity and $64 \%$ specificity. Its sensitivity and specificity for predicting mortality were $81 \%$ and $67 \%$, respectively. For the low-risk group (0 to 1 risk factor), which comprised $63 \%$ of the whole study population, the absolute risks of any hip fracture and of death were only $0.8 \%$ and $3.2 \%$, respectively (Figure 1). The corresponding risks for the high-risk group ( 2 to 4 risk factors) were $5.4 \%$ and

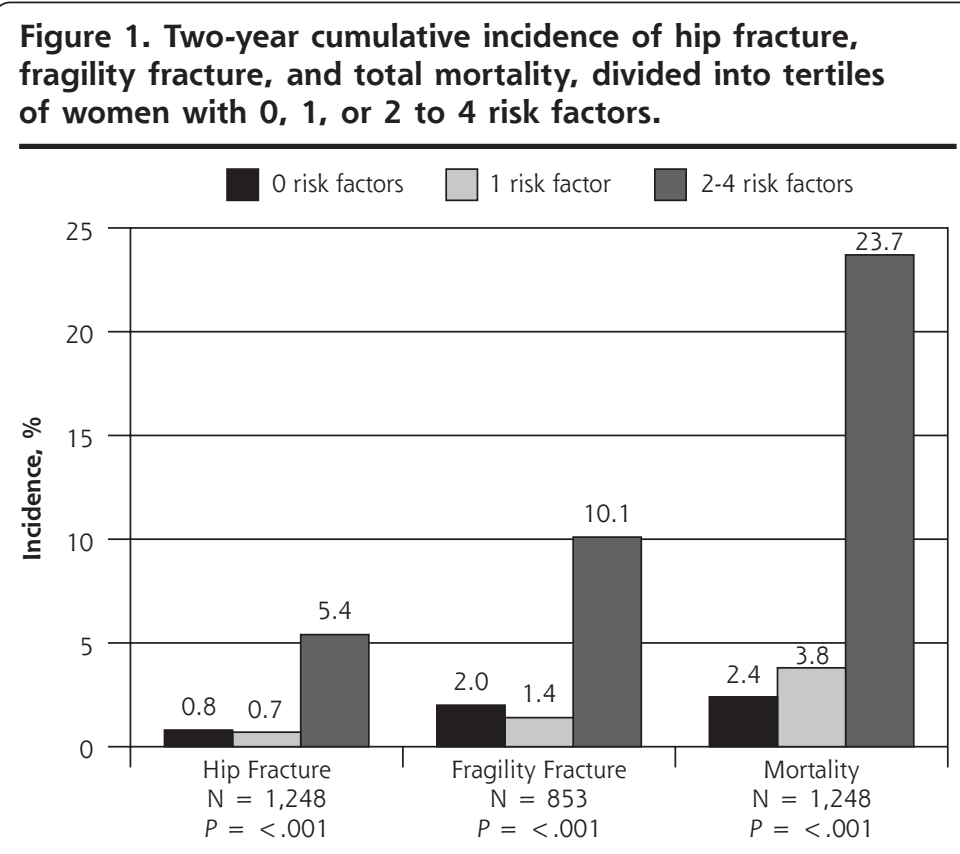

Note: Risk assessment with 0,1 , or 2 to 4 risk factors among age $\geq 80$ years, weight $<60 \mathrm{~kg}$, previous fragility fracture, and using arms to rise. The proportions of women with 0,1 , and 2 to 4 risk factors were $30 \%, 34 \%$, and $37 \%$, respectively.

Figure 2. Two-year cumulative incidence of hip fracture and total mortality according to number of risk factors.

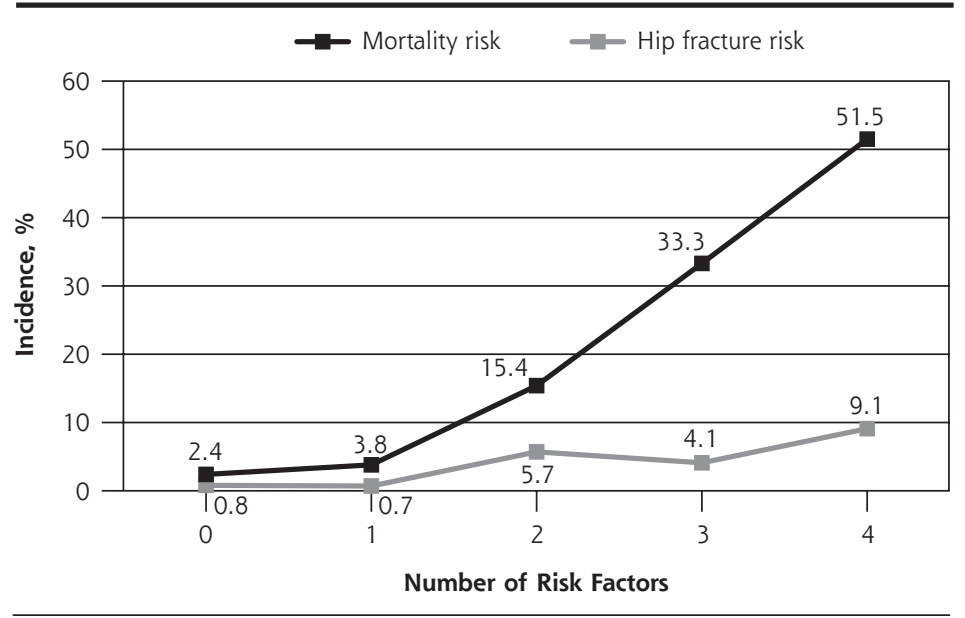

Note: Hip fracture and total mortality for women with $0,1,2,3$, or 4 risk factors among age $\geq 80$ years, weight $<60 \mathrm{~kg}$, previous fragility fracture, and using arms to rise. The proportions of women in these groups were $30 \%, 34 \%, 22 \%, 12 \%$, and $3 \%$, respectively.
23.7\%. Mortality increased significantly with the number of risk factors (Figure 2). The risk of hip fracture during the 2-year study period for the 2 risk groups is shown in Figure 3.

We defined in advance the high-risk threshold values for age and weight in the FRAMO Index and its application to create 2 risk groups (0-1 vs 2 - 4 risk factors). These levels proved appropriate, yielding an area under the ROC curve of 0.72 (95\% CI, 0.64-0.81) for hip fracture and 0.75 (95\% CI, 0.71-0.79) for mortality when all 1,248 women were analyzed. When the 4 risk factors were weighted (using continuous age and the risk factors' logistic regression coefficients), the area under the curve for hip fracture increased only slightly and nonsignificantly, to $0.75(P=.66)$. We chose the unweighted index because it is so easily calculated.

\section{Reported Vertebral Fracture}

The questionnaire given to all women included multiple-choice questions concerning different types of fractures occurring after the age of 40. An additional question about previous vertebral radiographs was sent only to the Vislanda population. Fully $10.0 \%$ of women from this district reported vertebral fractures, compared with $4.3 \%$ of the women from the other 2 districts (Tingsryd and Emmaboda) combined $(P<.001)$. When the FRAMO Index was applied to the Vislanda population only, its sensitivity for hip fracture was $92 \%$. The index yielded an area under the ROC curve of 0.78 for hip fracture in this population, compared with 0.68 in the remaining women, a nonsignificant difference $(P=.20)$.

\section{DISCUSSION}

\section{Main Findings}

We validated a very simple clinical risk model in a representative cohort of 1,248 women aged 70 years or older in 3 Swedish primary care populations. Eighty-three percent of this elderly population, which included women in residential care, responded to the questionnaire. The FRAMO Index consists of only 4 simply worded questions with yes/no answers, yet it predicts hip fractures as well as more complex risk 


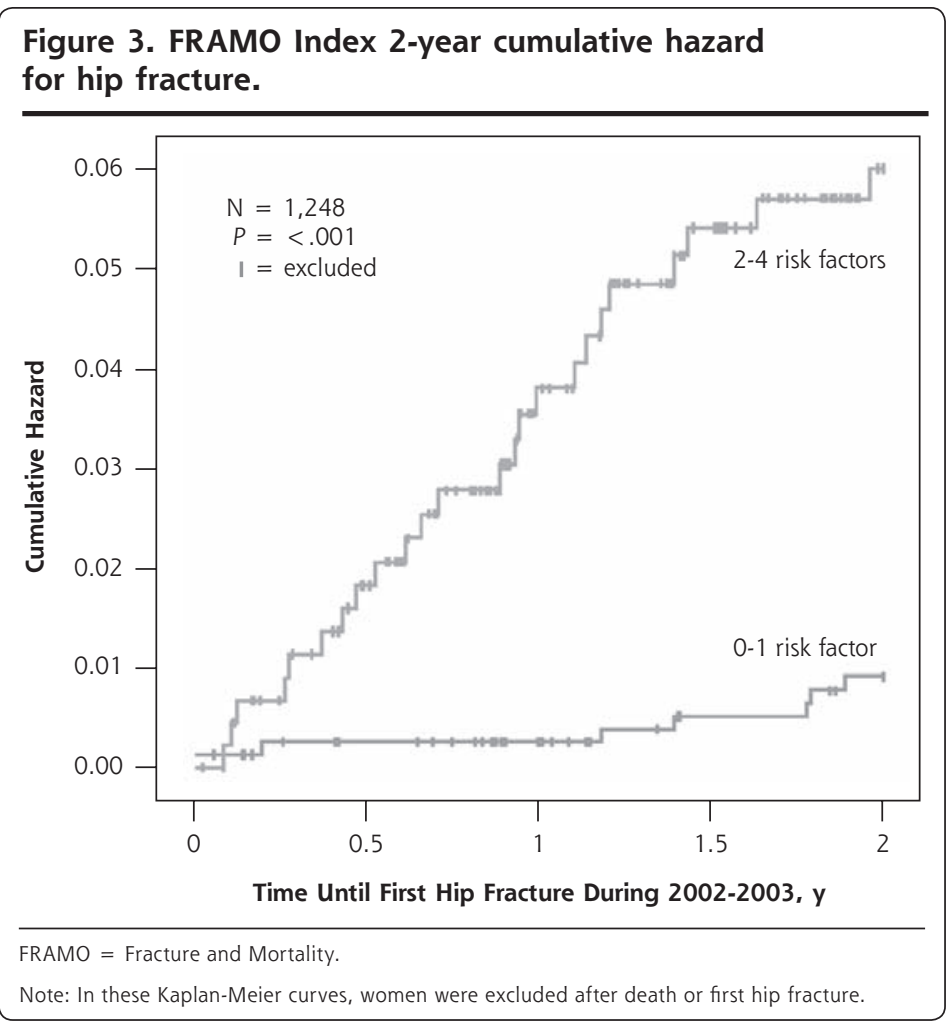

scoring systems. We found that a majority of women (63\%) had 0 or 1 risk factor, which was associated with very low absolute risks of hip fracture and total mortality within 2 years $(0.8 \%$ and $3.2 \%$, respectively). In contrast, the predicted hip fracture risk was more than 7 -fold greater for the $37 \%$ of women with at least 2 risk factors. Their risk for all types of fragility fractures was also increased. The mortality risk was more than 9-fold greater for women with the higher FRAMO Index score, and mortality increased steadily with the number of risk factors. After the FRAMO Index was adjusted for age, the risk estimates were still significant. Finally, we found that including a specific question about vertebral radiographs improved the reporting of previous vertebral fractures, which is an important predictor of future fractures ${ }^{13}$ and improves the sensitivity of the index.

\section{Limitations}

Although this study was small and few fractures occurred, the lower limits of the 95\% CIs for the ORs were at least 3.0 for the FRAMO Index. Because the number of incident fractures was small, only 3 individual risk factors remained significant predictors in univariate analysis after adjustment for age. Although the response rate was high, the $17 \%$ of women who were nonrespondents were somewhat older than respondents. This pattern probably decreased the actual risk estimates somewhat, because hip fractures become more common with age.

The observation period in this study was only 2 years. Because the FRAMO Index is simple and binary, with only yes/ no responses possible, this index is easy to repeat during regular consultation in primary care, even without use of the written questionnaire. Age as a binary variable may become less predictive during a longer observation period.

The number of fragility fractures that occurred during the study period was slightly underestimated. Hip, arm, and pelvic fractures are usually detected by radiographs, but not all women experiencing vertebral fractures are evaluated and given radiographic diagnoses.

This study was limited to white, rural, Swedish female populations, nearly all of whom (98\%) had parents of Nordic origin. Urban women, who have a higher fracture risk, more often have a history of fracture and are less physically active. ${ }^{17,18}$ Because these factors might be reflected in the index items of previous fragility fracture and using arms to rise, the index may also be suitable for fracture prediction in urban populations.

\section{Further Studies}

This study needs to be replicated in larger, non-Scandinavian, urban populations and possibly among both sexes (with modified variables for men), to obtain more precise fracture risk estimates. Also, the observation period should be extended. BMD measurement may improve the risk model, and the role of BMD in choosing strategies for fracture prevention can be more clearly defined. More information is needed to define different preventive treatments for different levels of risk.

\section{Comparison With Other Studies}

The age-adjusted ORs we observed for low weight and any type of previous fracture were similar to those in earlier studies. ${ }^{5,10}$ Despite the use of only 4 clinical risk factors applied in a strict binary fashion in our FRAMO Index, its sensitivity and specificity for 2-year hip fracture incidence were on par with those of previous studies with more complicated risk scoring. ${ }^{5,8,11}$

Similar risk factors have been used in other studies, in which scores for predicting the risk of hip fracture within 3,4 , or 5 years were created. ${ }^{4,5,11}$ In those studies, however, the variables of age or body weight were weighted, and a history of any type of fracture after age of 50 was used instead. 
The SOF 5 and the EPIDOS fracture study ${ }^{5}$ used a 7 item index. It included BMD as a significant independent predictor of the 5-year incidence of hip fracture. Inclusion of BMD increased the positive predictive value of that risk index slightly from $5.6 \%$ to $5.8 \%$. The index was validated for use in community-based volunteers, ${ }^{5}$ in contrast to our index, which was evaluated among women selected from total population registers for primary care areas.

In the MOF study, ${ }_{1}^{11}$ the risk model used to predict hip fracture within 3 years was more complex than our FRAMO Index, and the participation rate $(70 \%)$ was lower than that in our study $(83 \%)$.

\section{Implications}

Our very simple FRAMO Index was useful in identifying older women at high risk for hip fracture, fragility fracture, and mortality. The high response rate to the questionnaire may indicate a high level of interest in fracture prevention among this elderly female population. Population-based fracture risk assessment, including women in residential care, may be feasible using this method. This simple risk index might easily be applied during an ordinary consultation in primary care, even without the use of the written questionnaire

Of the independent predictors of hip fracture, such as impaired mobility, older age, previous fracture, or low $\mathrm{BMD}^{4-6}$ all but age are possibly modifiable risk factors. We have included age as a risk indicator in the FRAMO Index because fracture prevention may be most effective in older women. ${ }^{9}$ For example, bisphosphonates have been used for fracture prevention among postmenopausal women with previous vertebral fracture and osteoporosis. ${ }^{19,20}$ The absolute risk reduction for fracture increases with age (from age 55 years up to age 75 85 years) with bisphosphonate therapy, ${ }^{9,21}$ which is more cost-effective at age 77 years than at age 65 years. ${ }^{22}$

Data on the predictive value of the combination of BMD with the FRAMO Index are not yet available. A high FRAMO Index, like other clinical scores that include age, low weight, and previous fragility fracture, may identify women with osteoporosis; therefore, these 3 items have been used to select women for BMD testing. ${ }^{12,23,24}$ BMD assessment may delimit an even smaller group, at very high risk, who can derive more benefit from drugs to treat osteoporosis. ${ }^{4,5,21}$

Even more accurately, the FRAMO Index identifies a majority of women aged 70 years or older with minimal fracture or mortality risk who therefore have less of a need for fracture prevention interventions. For these women, BMD assessment may be unnecessary; according to the findings of the study by Cummings et $\mathrm{al}_{1}{ }^{4}$ women with few clinical risk factors are less likely to experience hip fracture, even if they are in the group with the lowest one third of BMD values. ${ }^{4}$
For postmenopausal women at all risk levels, clinicians should encourage basic lifestyle modifications to prevent fractures, such as regular physical activity, smoking cessation, and good nutrition, including adequate intakes of calcium and vitamin D. ${ }^{25-28}$ When the FRAMO Index shows that a patient is at high risk for fracture, several interventions may be valuable. Physical training may improve the ability to rise from sitting, ${ }^{29}$ and smoking cessation, walking outdoors, and daily physical activity are recommended. ${ }^{25,26,30,31}$ Training improves muscle strength and mobility, which may reduce the number of falls..$^{29,32,33}$ Also, a safer home environment and discontinuation of unnecessary psychotropic medication could reduce the tendency to fall. ${ }^{3-36}$ Hip protectors may prevent hip fracture among elderly individuals in institutional care. ${ }^{37}$ Clinicians should also consider pharmacologic treatment with calcium and vitamin $\mathrm{D}_{3}{ }^{38-43}$ and bisphosphonates. ${ }^{13,19,21,28,44,45}$

Because hip or spinal fracture itself increases the risk of mortality, ${ }^{46}$ preventing fractures may prolong life. Women with several risk factors who sustain hip fractures probably also require longer rehabilitation and have even shorter survival. This pattern might in turn warrant more active fracture prevention in this group.

The FRAMO Index, validated in this study, might be a practical fracture and survival assessment tool for clinicians to use during routine consultations.

To read or post commentaries in response to this article, see it online at http://www.annfammed.org/cgi/content/full/5/1/48.

Key words: Hip fractures; fractures, bone; mortality; women; aged; risk factors; risk assessment; primary health care; Sweden

Submitted September 14, 2005; submitted, revised, March 24, 2006; accepted April 4, 2006.

Previously presented at WONCA (17th World Conference of Family Doctors), October 16, 2004, Orlando, Fla.

Funding support: This study received financial and material support from the RED Center, Kronoberg County Council, Växjö.

Acknowledgments: Statistician Anna Lindgren provided substantial assistance with the statistical calculations.

\section{References}

1. Gullberg B, Johnell O, Kanis JA. World-wide projections for hip fracture. Osteoporos Int. 1997;7(5):407-413.

2. Kanis JA, Johnell O, Oden A, et al. Risk of hip fracture derived from relative risks: an analysis applied to the population of Sweden. Osteoporos Int. 2000;11(2):120-127.

3. Sernbo I, Johnell O. Consequences of a hip fracture: a prospective study over 1 year. Osteoporos Int. 1993;3(3):148-153.

4. Cummings SR, Nevitt MC, Browner WS, et al. Risk factors for hip fracture in white women. Study of Osteoporotic Fractures Research Group. N Engl J Med. 1995;332(12):767-773. 
5. Black DM, Steinbuch M, Palermo L, et al. An assessment tool for predicting fracture risk in postmenopausal women. Osteoporos Int. 2001;12(7):519-528.

6. Dargent-Molina P, Favier F, Grandjean H, et al. Fall-related factors and risk of hip fracture: the EPIDOS prospective study. Lancet. 1996;348(9021):145-149.

7. Taylor BC, Schreiner PJ, Stone KL, et al. Long-term prediction of incident hip fracture risk in elderly white women: Study of Osteoporotic Fractures. J Am Geriatr Soc. 2004;52(9):1479-1486.

8. De Laet CE, Van Hout BA, Burger $\mathrm{H}$, et al. Hip fracture prediction in elderly men and women: validation in the Rotterdam study. J Bone Miner Res. 1998;13(10):1587-1593.

9. De Laet CE, van Hout BA, Burger H, Hofman A, Pols HA. Bone density and risk of hip fracture in men and women: cross sectional analysis. BMJ. 1997;315(7102):221-225.

10. Kanis JA, Johnell O, De Laet $C$, et al. A meta-analysis of previous fracture and subsequent fracture risk. Bone. 2004;35(2):375-382.

11. McGrother CW, Donaldson MM, Clayton D, Abrams KR, Clarke M. Evaluation of a hip fracture risk score for assessing elderly women: the Melton Osteoporotic Fracture (MOF) study. Osteoporos Int. 2002;13(1):89-96.

12. Dargent-Molina P, Poitiers F, Breart G. In elderly women weight is the best predictor of a very low bone mineral density: evidence from the EPIDOS study. Osteoporos Int. 2000;11(10):881-888.

13. Klotzbuecher CM, Ross PD, Landsman PB, Abbott TA 3rd, Berger $M$. Patients with prior fractures have an increased risk of future fractures: a summary of the literature and statistical synthesis. J Bone Miner Res. 2000;15(4):721-739.

14. Gunnes M, Mellstrom D, Johnell O. How well can a previous fracture indicate a new fracture? A questionnaire study of 29,802 postmenopausal women. Acta Orthop Scand. 1998;69(5):508-512.

15. Albertsson D, Mellström D, Eggertsen R. Risk group for hip fracture in elderly women identified by primary care questionnaire-clinical implications. Ups J Med Sci. 2006;111(2):179-187.

16. Kullenberg R. Reference database for dual X-ray and laser Calscan bone densitometer. J Clin Densitom. 2003;6(4):367-372.

17. Jonsson B, Gardsell P, Johnell O, Redlund-Johnell I, Sernbo I. Differences in fracture pattern between an urban and a rural population: a comparative population-based study in southern Sweden. Osteoporos Int. 1992;2(6):269-273.

18. Jonsson B, Gardsell P, Johnell O, Sernbo I, Gullberg B. Life-style and different fracture prevalence: a cross-sectional comparative population-based study. Calcif Tissue Int. 1993;52(6):425-433.

19. Ensrud KE, Black DM, Palermo L, et al. Treatment with alendronate prevents fractures in women at highest risk: results from the Fracture Intervention Trial. Arch Intern Med. 1997;157(22):2617-2624.

20. Cummings SR, Black DM, Thompson DE, et al. Effect of alendronate on risk of fracture in women with low bone density but without vertebral fractures: results from the Fracture Intervention Trial. JAMA. 1998;280(24):2077-2082.

21. Hochberg MC, Thompson DE, Black DM, et al. Effect of alendronate on the age-specific incidence of symptomatic osteoporotic fractures. J Bone Miner Res. 2005;20(6):971-976.

22. Johnell $\mathrm{O}$, Jonsson $B$, Jonsson $L$, Black D. Cost effectiveness of alendronate (Fosamax) for the treatment of osteoporosis and prevention of fractures. Pharmacoeconomics. 2003;21(5):305-314.

23. Wehren LE, Siris ES. Beyond bone mineral density: can existing clinical risk assessment instruments identify women at increased risk of osteoporosis? J Intern Med. 2004;256(5):375-380.

24. Bauer DC, Browner WS, Cauley JA, et al. Factors associated with appendicular bone mass in older women. The Study of Osteoporotic Fractures Research Group. Ann Intern Med. 1993;118(9):657-665.

25. Paganini-Hill A, Chao A, Ross RK, Henderson BE. Exercise and other factors in the prevention of hip fracture: the Leisure World study. Epidemiology. 1991;2(1):16-25.
26. Feskanich D, Willett W, Colditz G. Walking and leisure-time activity and risk of hip fracture in postmenopausal women. JAMA. 2002;288(18):2300-2306.

27. Ringsberg KA, Gardsell P, Johnell O, Josefsson PO, Obrant KJ. The impact of long-term moderate physical activity on functional performance, bone mineral density and fracture incidence in elderly women. Gerontology. 2001;47(1):15-20.

28. Wilkins $\mathrm{CH}$, Birge SJ. Prevention of osteoporotic fractures in the elderly. Am J Med. 2005;118(11):1190-1195.

29. Fiatarone MA, Marks EC, Ryan ND, et al. High-intensity strength training in nonagenarians. Effects on skeletal muscle. JAMA. 1990;263(22):3029-3034.

30. Law MR, Hackshaw AK. A meta-analysis of cigarette smoking, bone mineral density and risk of hip fracture: recognition of a major effect. BMJ. 1997;315(7112):841-846.

31. Kanis JA, Johnell O, Oden A, et al. Smoking and fracture risk: a meta-analysis. Osteoporos Int. 2005;16(2):155-162.

32. Campbell AJ, Robertson MC, Gardner MM, Norton RN, Buchner DM. Falls prevention over 2 years: a randomized controlled trial in women 80 years and older. Age Ageing. 1999;28(6):513-518.

33. Day L, Fildes B, Gordon I, et al. Randomised factorial trial of falls prevention among older people living in their own homes. BMJ. 2002;325(7356):128-133.

34. Cumming RG, Thomas M, Szonyi G, et al. Home visits by an occupational therapist for assessment and modification of environmental hazards: a randomized trial of falls prevention. J Am Geriatr Soc. 1999;47(12):1397-1402.

35. Campbell AJ, Robertson MC, Gardner MM, Norton RN, Buchner DM. Psychotropic medication withdrawal and a home-based exercise program to prevent falls: a randomized, controlled trial. J Am Geriatr Soc. 1999;47(7):850-853.

36. Gillespie LD, Gillespie WJ, Robertson MC, et al. Interventions for preventing falls in elderly people. Cochrane Database Syst Rev. 2003;(4):CD000340.

37. Lauritzen JB, Petersen MM, Lund B. Effect of external hip protectors on hip fractures. Lancet. 1993;341(8836):11-13.

38. Bischoff-Ferrari HA, Dawson-Hughes $B$, Willett WC, et al. Effect of vitamin D on falls: a meta-analysis. JAMA. 2004;291(16):1999-2006.

39. Dawson-Hughes B, Harris SS, Krall EA, Dallal GE. Effect of calcium and vitamin $D$ supplementation on bone density in men and women 65 years of age or older. N Engl J Med. 1997;337(10):670-676.

40. Chapuy MC, Arlot ME, Duboeuf F, et al. Vitamin D3 and calcium to prevent hip fractures in the elderly women. $N$ Engl J Med. 1992;327(23):1637-1642.

41. Trivedi DP, Doll R, Khaw KT. Effect of four monthly oral vitamin D3 (cholecalciferol) supplementation on fractures and mortality in men and women living in the community: randomised double blind controlled trial. BMJ. 2003;326(7387):469-474

42. Bischoff-Ferrari HA, Willett WC, Wong JB, et al. Fracture prevention with vitamin D supplementation: a meta-analysis of randomized controlled trials. JAMA. 2005;293(18):2257-2264.

43. Larsen ER, Mosekilde L, Foldspang A. Vitamin D and calcium supplementation prevents osteoporotic fractures in elderly community dwelling residents: a pragmatic population-based 3-year intervention study. J Bone Miner Res. 2004;19(3):370-378.

44. Kanis JA, Black D, Cooper C, et al. A new approach to the development of assessment guidelines for osteoporosis. Osteoporos Int. 2002;13(7):527-536.

45. Black DM, Thompson DE, Bauer DC, et al. Fracture risk reduction with alendronate in women with osteoporosis: the Fracture Intervention Trial. FIT Research Group. J Clin Endocrinol Metab. 2000;85(11):4118-4124

46. Johnell O, Kanis JA, Oden A, et al. Mortality after osteoporotic frac tures. Osteoporos Int. 2004;15(1):38-42. 